\title{
Genetic Modifications of Saccharomyces cerevisiae for Ethanol Production from Starch Fermentation: A Review
}

\author{
Esra Aydemir, Selami Demirci, Ayşegül Doğan, Ali Özhan Aytekin and Fikrettin Sahin* \\ Department of Genetics and Bioengineering, Faculty of Engineering and Architecture, Yeditepe University, Turkey
}

\begin{abstract}
There is a huge demand for developing new technologies for alternative energy sources due to the elevated costs of petroleum and its by-products, depletion of nonrenewable fuel sources, and to eliminate the disadvantages of geopolitical location and environmental pollution caused by high levels of carbon dioxide release. Science is striving to meet this demand and as molecular biology techniques have progressed, genetic engineering tools have been presented as promising future solutions in the form of optimizing the fermentation process to increase the ethanol yield from different carbon sources such as starch. As Saccharomyces cerevisiae is not naturally able to ferment starch, it can be genetically manipulated and modulated to improve the fuel production from starchy materials and the amount of cost that is required to produce ethanol would be decreased with these manipulations. General modifications in S. cerevisiae include specific gene expressions to gain new properties or improve existing pathways. This review aims to elicit the current status of ethanol production thorough alternative techniques from starch using current genetic engineering applications and to give further directions for high-throughput fermentations using genetically modified S. cerevisiae strains.
\end{abstract}

Keywords: Saccharomyces cerevisiae; Ethanol; Fermentation; Genetic engineering; Starch

\section{Introduction}

Global energy consumption is rapidly increasing and it causes an elevation of energy cost and contributes to global warming because of the excessive use of petroleum based energy sources; hence the demand for renewable biomass-derived fuels has increased in recent years. Production of such alternative sources, which could also help establish a sustainable and renewable energy supply, has been popularized. Several countries have already used first generation biofuels, including ethanol, as a primary energy sources such that worldwide biofuel production reached 106 billion liters in 2011 and it is estimated to be 155 billion liters by 2020 [1]. Feedstocks rich in sugars are generally used for ethanol production via fermentation processes. Main sugar sources for ethanol production are presented in Figure 1. Although all of fuel ethanol is obtained from corn glucose in US [2] and sucrose in Brazil [3], starchy materials have been accepted as the major renewable biomass resources for ethanol production due to their low cost and abundance [4]. In this line, corn wheat and tubers from starchy crops are used for ethanol production in North America, Europe, and tropical countries [5].

Manipulation and utilization of starchy resources starts with enzymatic hydrolysis followed by fermentation of sugar molecules and subsequently the elimination of ethanol from culture media. Simultaneous Saccharification and Fermentation (SSF), is an alternative method used for bioethanol production from feedstock and it decreases fermentation costs by reducing equipment requirements since both processes occur in one reactor [6]. Another bonus in the SSF system is that the ethanol production rate is higher than the conventional method [7]. SSF has been applied for ethanol production from starch fermentation and remarkable ethanol yields ( 0.41 liter ethanol per $\mathrm{kg}$ of corn) have been obtained [8]. There have been attempts to increase the fermentation efficiency with immobilization of microorganisms in SSF systems [9-11]. Although SSF has advanced in the field, several points should be optimized to reduce the total cost, provide highly efficient utilization of starch, and maximize ethanol yield. These steps include: maintaining the optimal $\mathrm{pH}$ for the growth of fermentative microorganism, sterility, continuous substrate supplementation, and the establishment of cooling systems for high temperature fermentation systems [5]. Furthermore, several ethanol producing microorganisms used in industry, such as Saccharomyces cerevisiae, have strains that are not naturally able to utilize starch and they require high amounts of amylolytic enzymes, which is associated with high cost and impractical ethanol production [12]. Therefore, while ethanol production from starchy materials is racing ahead, the conventional processes used today are not favorable at the economic level; hence, improved methods are desired with microbial strains that enable efficiency and lead to high yield ethanol production in a cost-effective way [4].

A vast amount of microbial species to obtain ethanol from starch in the fermentation process have been presented in the literature. Regardless of the species, parental microorganisms remain insufficient in conventional ethanol production due to the lack of availability of sugar rich input and low ethanol yields. Over 150 amylolytic yeast strains have been reported to be impractical in industrial use because of limited characteristics [13]. Although Clostridium spp. and Zymomonas mobilis are popular bacteria for ethanol production [14,15], S. cerevisiae, well-known and widely used yeast in alcoholic beverages and bakery industries, is traditionally preferred because it sustains steady-state production, can consume various monomeric sugar molecules, has a high fermentation capacity, ethanol productivity and ethanol tolerance, along with having "generally regarded as safe" (GRAS) status [16]. As

*Corresponding author: Fikrettin Sahin, Department of Genetics and Bioengineering, Faculty of Engineering and Architecture, Yeditepe University, Kayisdagi, Atasehir, Istanbul, Turkey 34755, Tel: 902-165-780-619; Fax : 902165-780-829; E-mail: fsahin@yeditepe.edu.tr

Received August 16, 2014; Accepted October 14, 2014; Published October 17,2014

Citation: Aydemir E, Demirci S, Doğan A, Aytekin AO, Sahin F (2014) Genetic Modifications of Saccharomyces cerevisiae for Ethanol Production from Starch Fermentation: A Review. J Bioprocess Biotech 4: 180 doi: 10.4172/21559821.1000180

Copyright: (c) 2014 Aydemir E, et al. This is an open-access article distributed under the terms of the Creative Commons Attribution License, which permits unrestricted use, distribution, and reproduction in any medium, provided the original author and source are credited. 


\section{Crops}
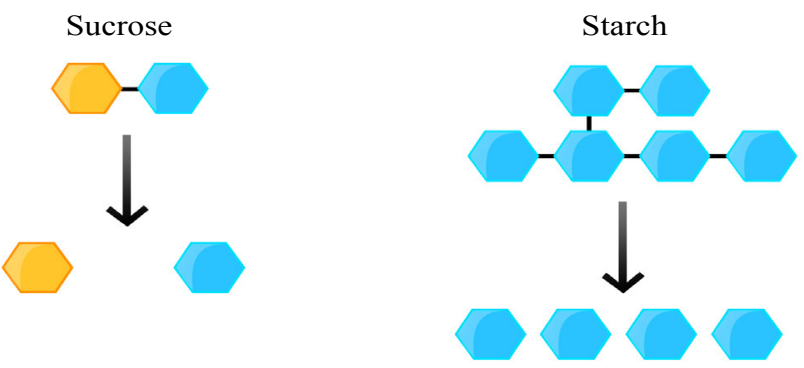

\section{Lignocellulose}

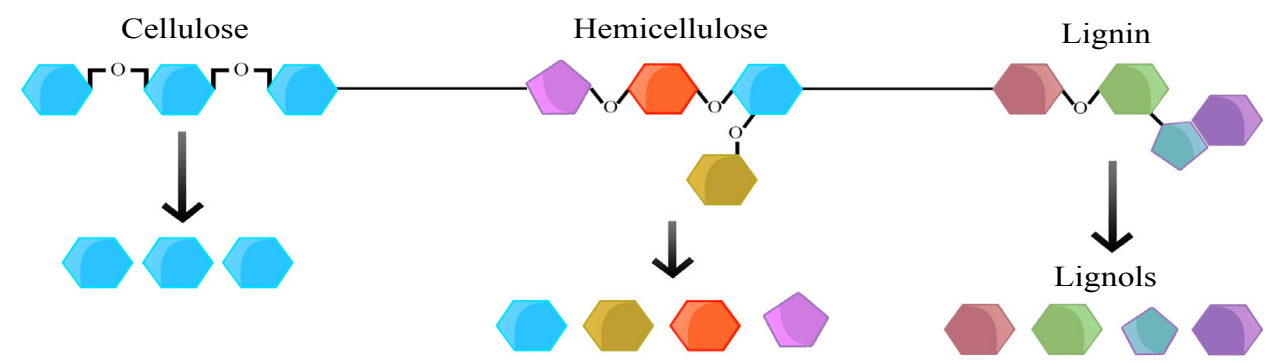

\section{Fructose \\ Glucose \\ Xylose \\ Mannose \\ Galactose}

Figure 1: Main sugar sources for ethanol fermentation.

S. cerevisiae is not naturally able to ferment starch, the development of genetically modified $S$. cerevisiae strains displaying starch utilizing enzymes ( $\alpha$-amylase and glucoamylase), leading to saccharification and fermentation of starch at the same time has been an area of interest. In this review the genetic engineering of $S$. cerevisiae to allow it to utilize starchy sources resulting in a decreased total cost of fermentation and the realization of high ethanol levels will be discussed in detail.

\section{Starch Fermentation}

Starch is a cheap, renewable, and fermentable carbon source [17] found in all green plants in various amounts. There is approximately a starch content of $70 \%$ in corn, triticale and cassava [18]. Starch molecules are generally associated with lipids, proteins and fatty acids, and the type of association determines the pre-treatment process to be applied before fermentation [19]. Starch consists of glucose monomers joined by glycosidic bonds ( $\alpha-1,4$ glucan-linked D-glucopyranose chains) [18]. It is mainly composed of the linear glucose polymer amylose (20-30\%) and highly branched amylopectin (70-80\%) (Figure 2) [20]. Amylose has mostly a-1,4-linked D-glucopyranose and sparse a-1,6-linked D-glucopyranose chains (about $0.3 \%$ to $0.5 \%$ ), and forms a flexible molecule leading to interaction with fatty acids, alcohols, and iodine [21]. Amylopectin is a highly branched helix like structured molecule consisting of $\alpha-1,4-D$-glucopyranose chains [22]. Amylose and amylopectin, found in the starch structure at different rates, form an interconnected structure which directly determines the chemical characteristic of biomass and fermentation yield [23].

Fermentation of starch commonly involves two stages; i) starch hydrolysis by amylolytic enzymes (liquefaction) and saccharification, ii) fermentation of glucose into ethanol [24]. For an efficient starch fermentation, both $\alpha-1,4$ and $\alpha$-1,6-debranching hydrolases, with amylases and glucoamylases, and $\alpha$-glucosidases displaying both $\alpha-1,4$ and $\alpha$-1,6-debranching activities are required [25]. As starch itself is not readily utilizable by $S$. cerevisiae, it has to be hydrolyzed by acid treatment and saccharificated by enzyme (amylase and/or glucoamylase) treatment before the main fermentation process [7]. This is a relatively expensive application as $30-40 \%$ of the total cost for the fermentation process is spent for the liquefaction and saccharification necessary for this popular microbe to be used [26]. Moreover, adding caustic soda, lime and sulphuric acid to maintain optimum $\mathrm{pH}$ levels for the enzymes, also increases the total cost [27]. Cold starch hydrolysis is an alternative method to decrease the total energy input. However, total enzyme requirement is much higher in cold hydrolysis than starch hydrolysis at high temperatures [28,29]. Although elevated temperatures in the initial step is advantageous to prevent bacterial contamination, high cooling cost result and become a major problem for fermentation because the temperature for industrially available yeasts should be stabilized to $30-37^{\circ} \mathrm{C}$. Co-culture systems (amylolytic microorganisms and yeast) have emerged in the SSF process to avoid pure enzyme requirements [30-32]. However, the process is still expensive and the ethanol yield is not satisfactory because of the high starch content consumed for the growth of amylolytic microorganisms. Consolidated Bioprocessing (CBP), hydrolysis and fermentation of sugar molecules in a single step using microorganisms with fermentation capability, is the most effective method for ethanol production from starch fermentation. In this concept, if a microorganism does not naturally express amylolytic enzymes, genetic engineering tools offer a solution for starch fermentation by non-amylolytic microorganisms, e.g. S. cerevisiae as explained in this review [18]. The optimization of temperature requirements for saccharification and fermentation processes and the development of genetically modified S. cerevisiae strains that do not need the addition of exogenous enzymes to achieve the full potential for starch fermentation in a single step, are highly 


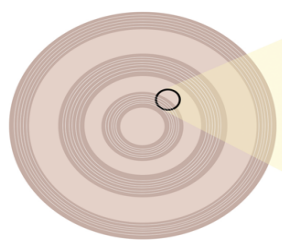

Starch granule

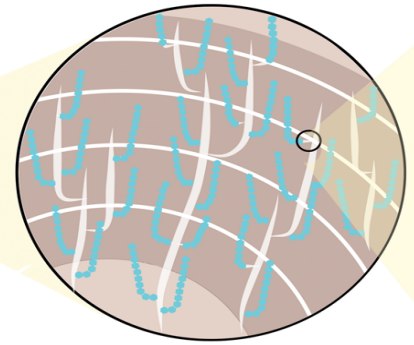

Starch strand
Amylose
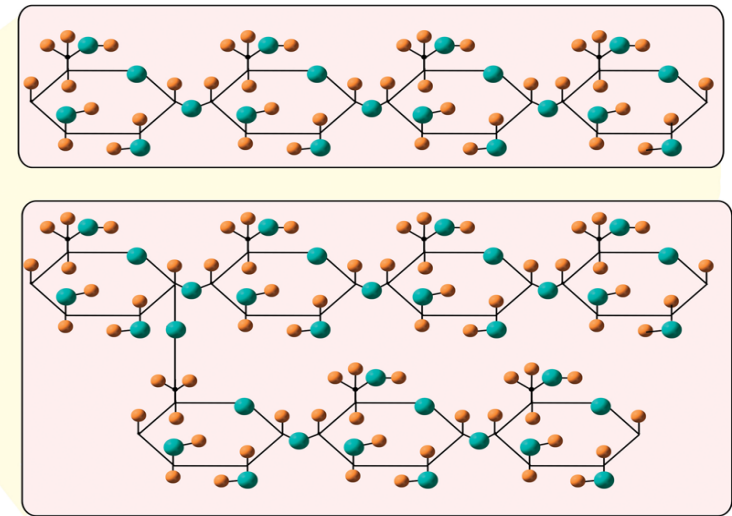

Amylopectin

Figure 2: Components and structure of starch.

warranted to enhance ethanol production $[16,33]$. Therefore, genetic manipulations in $S$. cerevisiae for a direct conversion of starch to ethanol is a promising process and it would save the feedstock spent for the growth of amylolytic microorganisms and reduce the total cost along with providing high ethanol yield.

\section{Glucoamylase expressing $S$. cerevisiae}

Construction of a yeast strain that can utilize raw starch has been studied since the 1980s [34,35]. In the beginning of genetically engineered S. cerevisiae, fashioned for starch fermentation, $13 \%(\mathrm{v} / \mathrm{v})$ ethanol yield was obtained from direct hydrolysis of starch via using glucoamylase expressing yeast [36]. The first step of the process began by constructing recombinant strains that express amylolytic enzymes ( $a$-amylase or glucoamylase) for the liquefaction and saccharification of the starchy biomass. Glucoamylase (1,4- $\alpha$-D-glucan glucohydrolase; EC 3.2.1.3) is recognized as the most important enzyme which is responsible for the progressive hydrolysis of starch from non-reducing ends to release $\beta$-D-glucose units and saccharification of the polymers [37]. The glucoamylase cDNA gene ( $g l u)$ from Aspergillus awamori has been successfully incorporated into $S$. cerevisiae genome for the utilization of starch and recombinant strains have been found to be stable for 50 generations without applying any selective pressure [38]. In another study, the glucoamylase enzyme coding sequence was transferred to $S$. cerevisiae genome and hydrolyzation of unprocessed and soluble starch was attained at high performance levels $\left(0.23 \mathrm{~g} . \mathrm{l}^{-1} \cdot \mathrm{h}^{-1}\right)$ [39]. The same research group also increased the enzyme activity of the A. awamori glucoamylase by codon-optimizing, compared to native glucoamylase (791 nkat and 591 nkat per gram dry cell weight, respectively) and transformed the recombinant gene to industrial $S$. cerevisiae (27P) strain for a direct starch fermentation [27]. Although co-culture of $S$. cerevisiae with an amylolytic microorganism is a conventional option, Nakamura et al. have reported that a recombinant S. cerevisiae, SR93, modified to express glucoamylase has produced

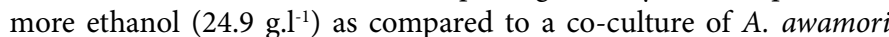
and wild type $S$. cerevisiae system $\left(22.0 \mathrm{~g}^{-\mathrm{l}^{-1}}\right)$, because SR93 has saved the internal starch amount consumed for the growth of the amylolytic microorganism, A. awamori [7]. However, SR93 could not degrade all the starch content efficiently because recombinant glucoamylase enzyme originated from Saccharomyces cerevisiae var. diastaticus was not able to degrade $a-1,6$ glycoside bond of amylopectin units. It has been recognized that this glucoamylase enzyme, coded by the STA1 gene, lacked a starch-binding domain which made fermentation and ethanol production unsatisfactory $[40,41]$. Therefore, the starch-binding domain of the Aspergillus niger glucoamylase gene has been fused with STA1 gene resulting in a remarkable hydrolysis and utilization of insoluble starch [42]. Instead of using a starch binding domain, the gene for glucoamylase of Rhizopus oryzae, capable of breaking down both $\alpha-1,4-$ and $\alpha-1,6$-glycosidic bond efficiently, has been transferred to $S$. cerevisiae and approximately $80 \%$ of starch content was utilized in a $100 \mathrm{~h}$ fermentation period [43]. As a long fermentation period $(\sim 150 \mathrm{~h})$ is required for sufficient starch fermentation by glucoamylase secreting S. cerevisiae, in anaerobic or minimal aerobic conditions $[7,34,35,44]$, a recombinant strain of $S$. cerevisiae (YF207/pGA11) expressing cell surface anchored $R$. oryzae glucoamylase has been tested for ethanol production under aerobic conditions (dissolved oxygen was $2.0 \mathrm{ppm}$ ), using soluble starch [4]. A high ethanol production rate $\left(0.71 \mathrm{~g} \cdot \mathrm{h}^{-1} \cdot \mathrm{l}^{-1}\right)$ was achieved and the fermentation process has been completed in seven repeated fermentations over $300 \mathrm{~h}$ without losing modified gene stability. As the same enzyme from various sources would provide different outcomes due to their divergent kinetic properties and activities in different experimental conditions, determining optimal enzyme source to be transferred is one of the most critical issues. For instance, $R$. arrhizus glucoamylase gene has been transferred to $S$.

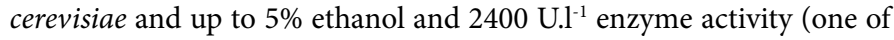
the highest level reported to date) has been obtained in a flask ferment experiment [45]. S. cerevisiae has been modified by Aspergillus oryzae glucoamylases, encoded by gla $A$ and glaB, and $R$. oryzae glucoamylase separately on the cell surface and compared with each other for their starch fermentation ability [46]. The highest ethanol yield has been obtained from glaA glucoamylase expressing yeast (15 g.l $\mathrm{l}^{-1}$ in $24 \mathrm{~h}$ ); although $R$. oryzae glucoamylase exhibited the highest glucoamylase activity $\left(9 \times 10^{-9} \mathrm{U} / \mathrm{cell}\right)$. From a different point of view, as raw and naive starch is not favorable from a commercial perspective, Kosugi et al. have designed an experiment to produce ethanol from cassava pulp rich in starch (up to 60\%) [47]. A high production rate of ethanol from 
$5 \%$ cassava pulp (91\% of theoretical value) has been achieved using $S$. cerevisiae displaying $R$. oryzae glucoamylase enzyme.

\section{a-amylase expressing $S$. cerevisiae}

Apart from transforming glucoamylase into S. cerevisiae for starch hydrolysis and saccharification, $\alpha$-amylase modification is another important option in recombinant technology for starch fermentation. The $\alpha$-amylases (EC 3.2.1.1) breakdown starch molecules from the internal $\alpha$-1,4-bonds of amylose and amylopectin and release dextrins (10-20 glucose units in length), free glucose and maltose units [37]. Wheat $\alpha$-amylase has been cloned into $S$. cerevisiae and found secreted into medium successfully as early as 1987 [48]. Since then, amylase enzymes from different sources such as bacterial [49], yeast [50,51], mold [52], barley [53] and rice [54] have been cloned into S. cerevisiae. From the beginning of these studies, optimization of cell growth and enzyme activity has been determined as the key factors for an efficient ethanol production. The selection of the source for the enzyme is a critical issue as the nature and activity of the enzyme should be compatible with the fermentation conditions. It has been shown that decrease in $\mathrm{pH}$, from 5.5 to 4.5 due to yeast growth, in fermentation resulted in a dramatic reduction in Bacillus subtilis $\alpha$-amylase activity, whereas there was no effect, even a slight increase, on barley $a$-amylase activity [55]. S. cerevisiae strains expressing recombinant a-amylase genes (LKA1 and LKA2) obtained from Lipomyces kononenkoae have been proven to convert starch directly into ethanol [56]. However, the rate of ethanol production has been found to be low (17.2 $\mathrm{g} . \mathrm{l}^{-1}$ in $200 \mathrm{~h}$ fermentation period) since the capacity of starch hydrolysis by recombinant $\alpha$-amylase was inadequate. Similarly, Ramachandran et al. have reported LKA1 expressing flocculent and non- flocculent S. cerevisiae strains for ethanol production from raw starch [57]. Genetically modified flocculent strains produced higher ethanol levels compared to non-flocculent counterparts (4.61 kg. $\mathrm{l}^{-1}$ and 5.1 g. $\mathrm{l}^{-1}$, respectively) in a $90 \mathrm{~h}$ fermentation period. However, the general accepted concept is that $S$. cerevisiae should express a high amount of $a$-amylase under aerobic conditions for effective starch fermentation $[56,58]$. As a different strategy, apart from genetically engineered $S$. cerevisiae that expresses recombinant $\alpha$-amylase, ethanol production rate sometimes increased by addition of exogenous glucoamylase enzyme [53,59]. Although this is a preferable option for a high starch fermentation rate, it is not economically favorable from an industrial perspective due to the high price of pure enzymes. In this line, scientists have focused on both a-amylase and glucoamylase expressing $S$. cerevisiae to increase ethanol yield and decrease total cost.

\section{Co-expression of $\alpha$-amylase and Glucoamylase}

In order to increase the rate of ethanol production from starch fermentation by $S$. cerevisiae, additional genetic manipulations such as co-expressing of $\alpha$-amylase and glucoamylase have emerged as a latter strategy. Glucoamylase and $\alpha$-amylase enzymes synergistically enhance the rate of corn and wheat starch hydrolysis with respect to their individual performances [51,60-62]. Hence, scientists have been working on constructing $S$. cerevisiae strains that express both enzymes. The glucoamylase gene of $A$. awamori (GA1), Debaryomyces occidentalis glucoamylase (GAM1), and a-amylase ( $A M Y)$ encoding plasmids have been transformed into industrial $S$. cerevisiae strain for a direct conversion of starch to ethanol [63]. Yeast containing GAM1, GA1 and AMY genes have exhibited the highest glucoamylase (required for debranching of starch molecules) activity (1020 $\mathrm{U.1}^{-1}$ ) compared to only GAM1 or GA1 transformed strains (790 U.1 ${ }^{1-1}$ and

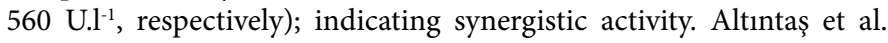

have also transformed $S$. cerevisiae with a bifunctional fusion protein that contained both the B. subtilis a-amylase and the A. awamori glucoamylase, but they have found the biomass (3.86-6.24 g. $\left.\mathrm{l}^{-1}\right)$ and ethanol production (18.4-23.2 g. $\left.\mathrm{l}^{-1}\right)$ insufficient in the experimental model of intermittent starch feeding system [64]. In a different study, three different recombinant strains of $S$. cerevisiae have been used for the comparison of their ethanol production capabilities [44]. YPG/AB strain expresses $B$. subtilis $\alpha$-amylase and the $A$. awamori glucoamylase separately, but YPB-G strain expresses both enzymes as a fusion protein. One last strain YPG/MM expresses mouse $\alpha$-amylase and $A$. awamori glucoamylase. YPG/AB strains were found to be superior in ethanol

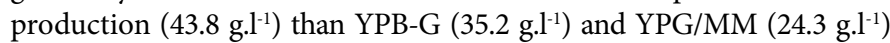
strains. Although the glucoamylase activity in YPG/AB and YPB-G

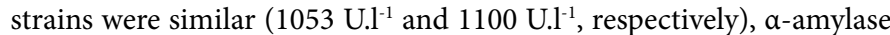
of YPG/AB showed 2.2 fold higher activity than the fusion protein group which was the possible explanation for the higher rate of ethanol production. In addition, low levels of ethanol produced by YPG/MM strain have been attributed to negligible glucoamylase activity. From a different point of view, expressing amylase and glucoamylase genes together with bacterial pullulanase in $S$. cerevisiae resulted in complete (99\%) utilization of the initial starch [65]. However, as it was mentioned in the previous section, using laboratory strains and raw starch resources are not economically favorable and do not always reflect real conditions. In this sense, scientists have tried to optimize starch fermentation using unprocessed biomass and industrial yeast strains. In a high-yielding brown rice fermentation, yeast strain expressing a-amylase and glucoamylase exhibited acceptable ethanol production rate $\left(1.1 \mathrm{~g} . \mathrm{l}^{-1} \cdot \mathrm{h}^{-1}\right)$ [66]. Industrial yeast strains have also been genetically modified for starch hydrolysis due to their high ethanol production rate and tolerance to harsh conditions. Viktor et al. have tested ethanol production capacities of Aspergillus tubingensis T8.4 a-amylase and glucoamylase expressing laboratory strain, S. cerevisiae Y294, and the semi-industrial strain, S. cerevisiae Mnua1. Y294 and Mnual strains have produced 9.03 and $6.67 \mathrm{~g}^{-1}{ }^{-1}$ ethanol, respectively, from a substrate load of $200 \mathrm{~g} . \mathrm{l}^{-1}$ raw corn starch after 10 days fermentation period without any heat treatment [37]. Industrial strains of S. cerevisiae have been transformed with amylase and glucoamylase genes separately and co-cultured for an efficient one-step starch utilization [67]. Activities for glucoamylase and $\alpha$-amylase have been determined as $920 \mathrm{U}^{-l^{-1}}$ and $7960{\mathrm{U} . \mathrm{l}^{-1}}^{1}$, respectively.

\section{Cell surface anchored enzyme expressing $S$. cerevisiae strains}

Co-expressing of starch utilizing enzymes has also been studied by anchoring enzymes on the cell wall of yeast to provide long term durability. Expressing on the cell surface and secreting to the medium has various advantages and disadvantages. Secreting of the enzymes to the fermentation environment increases the rate and amount of ethanol by providing high possibility of interaction between starch molecules and enzymes [68]. On the other hand, secreting to the environment is not favorable because of the loss of stability in the early stage of fermentation. An additional consideration for secreted enzymes is including extra ingredients such as metal ions or surfactants in the fermentation medium to provide enzyme stability for repeated largescale productions. For example, calcium ions have been claimed to be protective for $a$-amylase during repeated 10-cycles of raw starch fermentation [69]. However, cell surface engineering of yeast for starch utilizing enzymes is suitable for long term stability and repeated largescale production without the necessity of adding additional reagents. In a recent study, $S$. cerevisiae strain co-expressing glucoamylase 
and $\alpha$-amylase on the cell surface has been used in 23 continuous cycles of ethanol fermentation without losing enzyme activity [70]. Recombinant yeast strains, glucoamylase and $\alpha$-amylase anchored on the cell wall (or secreted to the medium), have been developed for a direct starch utilization [71]. Cell surface glucoamylase and $\alpha$-amylase expressing S. cerevisiae strain has produced more ethanol (60 g. $\mathrm{l}^{-1}$ in a $100 \mathrm{~h}$ fermentation period) and a higher starch degradation rate than the only cell surface glucoamylase expressing strain $\left(50 \mathrm{~g} . \mathrm{l}^{-1}\right.$ in $120 \mathrm{~h}$ fermentation). In another study, S. cerevisiae co-displaying glucoamylase of $R$. oryzae and a-amylase of Streptococcus bovis anchored to cell membrane via $\mathrm{C}$-terminal-half region of $\alpha$-agglutinin and the flocculation functional domain of Flo1p, respectively, has been effective (61.8 g. $^{-1}$ ethanol in a $72 \mathrm{~h}$ fermentation period) in raw corn starch hydrolysis [12]. A recent study has brought a different point of view to starch conversion into ethanol by S. cerevisiae. A recombinant strain of yeast which expressed cell surface engineered aspartic protease has been constructed for the consuming of complex nitrogenous materials, other than starchy molecules found in crops, that resulted in high ethanol yield and shorter fermentation duration $3.8 \pm 0.15 \%$ improvement in the final ethanol concentration compared to parental strain in $72 \mathrm{~h}$ fermentation period) [72].

\section{Stable Starch Fermenting S. cerevisiae Strains}

Although genetic manipulation is a relatively easy process by using episomal vectors which do not require integrative sites, the stability of the episomal plasmid is a serious problem for long-term and repeated fermentation such that plasmid leakage is generally observed in longterm incubation $[7,73]$. Gene integration into the microbial genome has been undertaken in many studies to provide long-term enzyme activity $[38,74,75]$. The $\delta$-sequences of the Ty retrotransposon, or rDNA sequence, of $S$. cerevisiae are generally used elements for chromosomal integration of a recombinant gene. Enzyme activities could be increased 20 -fold by means of $\delta$-integration sequence with respect to the conventional transformation [76]. In another study, it has been shown that $90 \%$ of the initial starch content was fermented by recombinant $S$. cerevisiae that co-expressed glucoamylase and $\alpha$-amylase transformed via $\delta$-integration [77]. Although, there has been a 2 -fold decrease in ethanol production and cell mass in S. cerevisiae strain transformed with episomal vector after 7-repeated fermentation process, the yeast strain transformed with $\delta$-integration sequence containing plasmid has exhibited long term stability of enzyme activity up to 10 cycles $[69,78]$ and a high ethanol production rate up to 23 cycles [70]. Ribosomal DNA sequence of yeast is another effective option for chromosomal integration via homologous recombination. An $\alpha$-amylase gene has been integrated into yeast chromosome and exhibited a 2 -fold increase in starch consumption compared to the episomal vector cloned strain [79]. Targeting ribosomal DNA sequence (150-200 copy in yeast genome) via homologous recombination has resulted in stable high copy number of recombinant gene $[59,80]$. Multiple copy integrated genes via rDNA homologous recombination displayed a higher quantity of starch consumption and ethanol production (19.2 g. $\left.\mathrm{l}^{-1}\right)$ [81]. As a novel strategy, rDNA and $\delta$-integration combination could be used by targeting two separate DNA sites for efficient cloning of two or more genes [63]. Cell fusion technique is also used to make diploid and tetraploid S. cerevisiae strains to obtain high level of biomass and ethanol production. Diploid and tetraploid strains have proliferated and grown faster, fermented starch more efficiently in comparison with parental strains. At the end of $72 \mathrm{~h}$ fermentation process, haploid, diploid and tetraploid strains have produced $0.55,0.72$ and $0.93 \mathrm{~g} . \mathrm{l}^{-1} \cdot \mathrm{h}^{-1}$ ethanol, respectively [76].

\section{Conclusion and Future Perspectives}

Energy prices are growing fast, mainly because of depletion of petroleum sources. Therefore, alternative energy sources obtained from sun, wind and biomass have become attractive recently. Ethanol, produced by fermentation from biomass, as a promising alternative energy is a transportable and economically favorable source. In addition, ethanol production from various feedstocks such as starch maintains a considerable potential due to their availability, accessibility and relatively low cost in comparison to sucrose and glucose based feedstocks. Recombinant DNA technology offers a valuable opportunity for consolidated bioprocessing processes of the biomass fermentation. To date however, transforming new pathways and overexpression of a single or group of enzymes have

\begin{tabular}{|c|c|c|c|c|c|c|}
\hline Engineered Enzyme & Gene Source & $\begin{array}{l}\text { Cultivation } \\
\text { Time (h) }\end{array}$ & $\begin{array}{c}\text { Ethanol Yield } \\
\left(g \cdot l^{-1} \cdot h^{-1}\right)\end{array}$ & $\begin{array}{l}\text { Enzyme } \\
\text { Activity }\end{array}$ & Starch Source & Reference \\
\hline a-amylase & Lipomyces kononenkoae & 90 & 0.05 & $87 \mathrm{U.I}^{-1}$ & Raw corn starch & {$[57]$} \\
\hline Glucoamylase & Aspergillus awamori & $\mathrm{NA}^{*}$ & ND & $162 U . .^{-1}$ & Soluble starch & [38] \\
\hline Glucoamylase & Aspergillus awamori & 50 & 0.23 & $624 U^{. I^{-1}}$ & Soluble starch & [39] \\
\hline Glucoamylase & $\begin{array}{l}\text { Saccharomyces diastaticus } \\
\text { (var. diastaticus) }\end{array}$ & 200 & 0.66 & ND & Soluble starch & {$[7]$} \\
\hline Glucoamylase & Rhizopus oryzae & 168 & 0.77 & $\begin{array}{l}60.2 \mathrm{U} / \mathrm{g} \text { of wet } \\
\text { cells }\end{array}$ & $\begin{array}{l}\text { Cassava pulp rich in } \\
\text { starch }(60 \%)\end{array}$ & {$[47]$} \\
\hline Glucoamylase & Aspergillus awamori & 80 & 0.175 & ND & Soluble starch & {$[58]$} \\
\hline $\begin{array}{l}\text { Glucoamylase/ } \\
\text { a-amylase }\end{array}$ & Rhizopus oryzae/ Streptococcus bovis & 72 & 0.85 & $\begin{array}{l}57 / 114 \mathrm{U} / \mathrm{g} \text { of } \\
\text { wet cells }\end{array}$ & Raw corn starch & [12] \\
\hline $\begin{array}{l}\text { Glucoamylase/ } \\
\text { a-amylase }\end{array}$ & $\begin{array}{l}\text { Saccharomycopsis fibuligera/ } \\
\text { Lipomyces kononenkoae }\end{array}$ & 120 & 0.178 & $1340 /<30{\mathrm{U} . \mathrm{I}^{-1}}^{-1}$ & Soluble starch & {$[56]$} \\
\hline $\begin{array}{l}\text { Glucoamylase/ } \\
\text { a-amylase }\end{array}$ & Rhizopus oryzae/ Streptococcus bovis & 120 & 0.74 & $790 / 1306$ U. $^{-1}$ & Raw corn starch & [70] \\
\hline $\begin{array}{l}\text { Glucoamylase/ } \\
\text { a-amylase }\end{array}$ & Rhizopus oryzae/ Streptococcus bovis & 24 & 1.2 & $4700 / 1800{\mathrm{U} . \mathrm{I}^{-1}}^{-1}$ & High-yielding rice & {$[66]$} \\
\hline $\begin{array}{l}\text { a-amylase/ glucoamylase/ } \\
\text { glucoamylase with debranching activity }\end{array}$ & $\begin{array}{c}\text { Debaryomyces occidentalis/ Aspergillus } \\
\text { awamori/ Debaryomyces occidentalis }\end{array}$ & 168 & 0.45 & $5940 / 1020$ U..$^{-1}$ & Soluble starch & [63] \\
\hline $\begin{array}{c}\text { Glucoamylase/ } \\
\text { isoamylase }\end{array}$ & $\begin{array}{c}\text { Aspergillus awamori/ } \\
\text { Pseudomonas amyloderamosa }\end{array}$ & 140 & 0.137 & ND & Soluble starch & {$[81]$} \\
\hline
\end{tabular}

"NA: Not available,

\#ND: Not determined 
not taken biomass fermentation via $S$. cerevisiae to a satisfactory level for industrial arena. Although there are hundreds of studies claiming higher ethanol production from starchy materials, most of these have been tested at laboratory scale only and not at large-scale (Table 1). Several laboratory yeast strains have been proven to exhibit remarkable starch fermenting capacity and produce high amounts of ethanol, but transferring engineering technology to industrial S. cerevisiae strains has remained insufficient. They are not convenient for repeated large scale applications because of low stability of the modification, high cost of the process, low yield of ethanol production and fermentation rate. Although using exogenous amylase and glucoamylase seems to increase total yield, developing yeast strains sufficient alone for the whole fermentation process is desirable. New amylase and glucoamylase from different sources should be presented and investigated for their activity (alone or in combination) and compatibility with industrial yeast stains. Researchers should continue to conduct studies on two main areas; efficient hydrolysis and fermentation of biomass, which result in high ethanol production rate and combination of improved bioprocess applications with genetic engineering tools in the view of productivity and large scale processes.

\section{Acknowledgment}

This review was supported by Yeditepe University, Istanbul, Turkey. The authors would like to thank to Lynne Emily Ozgur for her numerous suggestions on language.

\section{References}

1. (2012) OECD-FAO Agricultural Outlook 2011-2020.

2. (2001) US Ethanol Industry:Production capacity outlook. Results of a Survey Conducted by the California Energy Commission. California Energy Commission.

3. Rosillo-Calle F, Cortez LAB (1998) Towards proalcohol II: A review of the Brazilian bioethanol programme. Biomass Bioenergy 14: 115-124.

4. Kondo A, Shigechi H, Abe M, Uyama K, Matsumoto T, et al. (2002) High-leve ethanol production from starch by a flocculent Saccharomyces cerevisiae strain displaying cell-surface glucoamylase. Appl Microbiol Biotechnol 58: 291-296.

5. Cardona CA, Sánchez OJ (2007) Fuel ethanol production: process design trends and integration opportunities. Bioresour Technol 98: 2415-2457.

6. Wyman CE (1994) Ethanol from lignocellulosic biomass: Technology, economics and opportunities. Bioresour Technol 50: 3-16.

7. Nakamura Y, Kobayashi F, Ohnaga M, Sawada T (1997) Alcohol fermentation of starch by a genetic recombinant yeast having glucoamylase activity. Biotechnol Bioeng 53: 21-25.

8. Madson PW, Monceaux DA (1995) Fuel ethanol production. Nottingham University Press, 1-12

9. Chithra N, Baradarajan A (1992) Direct conversion of starch hydrolysate to ethanol using a coimmobilizate of amyloglucosidase and Saccharomyces cerevisiae in batch stirred tank reactor. Bioprocess Eng 7: 265-267.

10. Farid MA, El-Enshasy HA, Noor El-DeenAM (2002) Alcohol production from starch by mixed cultures of Aspergillusawamori and immobilized Saccharomyces cerevisiae at different agitation speeds. J Basic Microbiol 42 $162-171$

11. Kurosawa H, Nomura N, Tanaka H (1989) Ethanol production from starch by a coimmobilized mixed culture system of Aspergillusawamori and Saccharomyces cerevisiae. Biotechnol Bioeng 33: 716-723.

12. Shigechi H, Koh J, Fujita Y, Matsumoto T, Bito Y, et al. (2004) Direct production of ethanol from raw corn starch via fermentation by use of a novel surfaceengineered yeast strain codisplayingglucoamylase and alpha-amylase. Appl Environ Microbiol 70: 5037-5040.

13. ToksoyOner E, Oliver SG, Kirdar B (2005) Production of ethanol from starch by respiration-deficient recombinant Saccharomyces cerevisiae. Appl Environ Microbiol 71: 6443-6445
14. Gunasekaran P, Raj KC (1999) Ethanol fermentation technologyZymomonasmobilis. Curr Sci 77: 56-68.

15. Pfromm PH, Amanor-Boadu V, Nelson R, Vadlani P, Madl R (2010) Bio-butanol vs. bio-ethanol: A technical and economic assessment for corn and switchgrass fermented by yeast or Clostridium acetobutylicum. Biomass Bioenergy 34: 515524

16. Görgens JF, Bressler DC, van Rensburg E (2014) Engineering Saccharomyces cerevisiae for direct conversion of raw, uncooked or granular starch to ethanol. Crit Rev Biotechnol

17. Ülgen KÖ, Saygili B, Önsan ZI, Kirdar B (2002) Bioconversion of starch into ethanol by a recombinant Saccharomyces cerevisiae strain YPG-AB. Process Biochem 37: 1157-1168.

18. vanZyl WH, Bloom M, Viktor MJ (2012) Engineering yeasts for raw starch conversion. Appl Microbiol Biotechnol 95: 1377-1388.

19. BeMiller JN, Whistler RL (2009) Structural features of starch granules II. Starch: Chemistry and technology. (3rd edition), Academic Press, New York and London.

20. Yamada R, Bito Y, Adachi T, Tanaka T, Ogino C, et al. (2009) Efficient production of ethanol from raw starch by a mated diploid Saccharomyces cerevisiae with integrated a-amylase and glucoamylase genes. Enzyme Microb Technol 44 344-349.

21. Whistler RL, BeMiller JN (1997) Carbohydrate chemistry for food scientists. Eagan Press, St. Paul, Minnesota, USA.

22. Stevnebø A, Sahlström S, Svihus B (2006) Starch structure and degree of starch hydrolysis of small and large starch granules from barley varieties with varying amylose content. Anim Feed Sci Technol 130: 23-38.

23. Klucinec JD, Thompson DB (2002) Amylopectin nature and amylose-toamylopectin ratio as influences on the behavior of gels of dispersed starch Cereal Chem 79: 24-35.

24. Lee WS, Chen IC, Chang CH, Yang SS (2012) Bioethanol production from sweet potato by co-immobilization of saccharolytic molds and Saccharomyces cerevisiae. Renew Energ 39: 216-222.

25. van der Maarel MJ, van der Veen B, Uitdehaag JC, Leemhuis H, Dijkhuizen L (2002) Properties and applications of starch-converting enzymes of the alphaamylase family. J Biotechnol 94: 137-155.

26. Wu Q, Miao Y (2008) Mechanochemical effects of micronization on enzymatic hydrolysis of corn flour. Carbohydr Polym 72: 398-402.

27. Favaro L, Jooste T, Basaglia M, Rose SH, Saayman M, et al. (2012) Codonoptimized glucoamylasesGAl of Aspergillus awamori improves starch utilization in an industrial yeast. Appl Microbiol Biotechnol 95: 957-968.

28. Lang X, Macdonald D, Hill G (2001) Recycle bioreactor for bioethanol production from wheat starch II. Fermentation and economics. Energ Source 23: 427-436.

29. Robertson GH, Wong DW, Lee CC, Wagschal K, Smith MR, et al. (2006) Native or raw starch digestion: a key step in energy efficient biorefining of grain. J Agric Food Chem 54: 353-365.

30. Manikandan K, Viruthagiri T (2009) Simultaneous saccharification and fermentation of wheat bran flour into ethanol using coculture of amyloticAspergillusniger and thermotolerantKluyveromycesmarxianus. Front Chem Eng China 3: 240-249.

31. Suresh K, Kiran Sree NRao LV (1999) Utilization of damaged sorghum and rice grains for ethanol production by simultaneous saccharification and fermentation. Bioresour Technol 68: 301-304.

32. Verma G, Nigam P, Singh D, Chaudhary K (2000) Bioconversion of starch to ethanol in a single-step process by coculture of amylolytic yeasts and Saccharomyces cerevisiae 21. Bioresour Technol 72: 261-266.

33. Dogan A, Demirci S, Aytekin AÖ, Sahin F (2014) Improvements of Tolerance to Stress Conditions by Genetic Engineering in Saccharomyces cerevisiae during Ethanol Production. Appl Biochem Biotechnol 174: 28-42.

34. Cole GE, McCabe PC, Inlow D, Gelfand DH, Ben-Bassat A, et al. (1988) Stable Expression of Aspercillus awamori Glucoamylase in Distiller's Yeast. Nat Biotechnol 6: 417-421.

35. Innis MA, Holland MJ, McCabe PC, Cole GE, Wittman VP, et al. (1985) Expression, Glycosylation, and Secretion of an Aspergillus Glucoamylase by Saccharomyces cerevisiae. Science 228: 21-26. 
36. Ashikari T, Kunikasi S, Matsumoto N Amachi T, Yoshizumi H (1989) Direct fermentation of raw corn to ethanol by yeast transformants containing a modified Rhizopusglucoamylase gene. Appl Microbiol Biotechnol 32: 129-133.

37. Viktor MJ, Rose SH, Van Zyl WH, Viljoen-Bloom M (2013) Raw starch conversion by Saccharomyces cerevisiae expressing Aspergillus tubingensis amylases. Biotechnol Biofuels 6: 167-177.

38. Lin LL, Ma YJ, Chien HR, Hsu WH (1998) Construction of an amylolytic yeas by multiple integration of the Aspergillus awamori glucoamylase gene into a Saccharomyces cerevisiae chromosome. Enzyme Microb Technol 23: 360-365.

39. Favaro L, Jooste T, Basaglia M, Rose SH, Saayman M, et al. (2013) Designing industrial yeasts for the consolidated bioprocessing of starchy biomass to ethanol. Bioengineered 4: 97-102.

40. Adam AC, Latorre-García L, Polaina J (2004) Structural analysis of glucoamylase encoded by the STA1 gene of Saccharomyces cerevisiae (var. diastaticus). Yeast 21: 379-388

41. Sevcík J, Solovicová A, Hostinová E, Gasperík J, Wilson KS, et al. (1998) Structure of glucoamylase from Saccharomycopsis fibuligera at 1.7 A resolution. Acta Crystallogr D Biol Crystallogr 54: 854-866.

42. Latorre-García L, Adam AC, Manzanares P, Polaina J (2005) Improving the amylolytic activity of Saccharomyces cerevisiae glucoamylase by the addition of a starch binding domain. J Biotechnol 118: 167-176.

43. Murai T, Ueda M, Yamamura M, Atomi H, Shibasaki Y, et al. (1997) Construction of a starch-utilizing yeast by cell surface engineering. Appl Environ Microbio 63: $1362-1366$.

44. Birol G, Önsan ZI, Kirdar B, Oliver SG (1998) Ethanol production and fermentation characteristics of recombinant saccharomyces cerevisiae strains grown on starch. Enzyme Microb Technol 22: 672-677.

45. Yang S, Jia N, Li M, Wang J (2011) Heterologous expression and efficien ethanol production of a Rhizopus glucoamylase gene in Saccharomyces cerevisiae. Mol Biol Rep 38: 59-64.

46. Kotaka A, Sahara H, Hata Y, Abe Y, Kondo A, et al. (2008) Efficient and direct fermentation of starch to ethanol by sake yeast strains displaying fungal glucoamylases. Biosci Biotechnol Biochem 72: 1376-1379.

47. Kosugi A, Kondo A, Ueda M, Murata Y, Vaithanomsat P, et al. (2009) Production of ethanol from cassava pulp via fermentation with a surface-engineered yeast strain displaying glucoamylase. Renew Energ 34: 1354-1358.

48. Rothstein SJ, Lahners KN, Lazarus CM, Baulcombe DC, Gatenby AA (1987) Synthesis and secretion of wheat alpha-amylase in Saccharomyces cerevisiae. Gene 55: 353-356.

49. Kovaleva IE, Novikova LA, Luzikov VN (1989) Synthesis and secretion of bacterial alpha-amylase by the yeast Saccharomyces cerevisiae. FEBS Lett 251: 183-186.

50. Kang NY, Park JN, Chin JE, Lee HB, Im SY, et al. (2003) Construction of an amylolytic industrial strain of Saccharomyces cerevisiae containing the Schwanniomy cesoccidentalis alpha-amylase gene. Biotechnol Lett 25: 1847 1851.

51. Steyn AJ, Pretorius IS (1995) Characterization of a novel alpha-amylase from Lipomyces kononenkoae and expression of its gene (LKA1) in Saccharomyces cerevisiae. Curr Genet 28: 526-533.

52. Randez-Gil F, Sanz P (1993) Expression of Aspergillus oryzae alpha-amylase gene in Saccharomyces cerevisiae. FEMS Microbiol Lett 112: 119-123.

53. Liao B, Hill GA, Roesler WJ (2010) Amylolytic activity and fermentative ability of Saccharomyces cerevisiae strains that express barley $\alpha$-amylase. Biochem Eng J 53: 63-70.

54. Kumagai MH, Shah M, Terashima M, Vrkljan Z, Whitaker JR, et al. (1990) Expression and secretion of rice alpha-amylase by Saccharomyces cerevisiae. Gene 94: 209-216.

55. Textor SD, Hill GA, MacDonald DG, Denis ES (1998) Cold enzyme hydrolysis of wheat starch granules. Can J Chem Eng 76: 87-93.

56. Knox AM, du Preez JC, Kilian SG (2004) Starch fermentation characteristics of Saccharomyces cerevisiae strains transformed with amylase genes from Lipomyces kononenkoae and Saccharomycopsis fibuligera. Enzyme Microb Technol 34: 453-460.
57. Ramachandran N, Joubert L, Gundlapalli SB, Otero RRC, Pretorius IS (2008) The effect of flocculation on the efficiency of raw-starch fermentation by Saccharomyces cerevisiae producing the Lipomyces kononenkoae LKA1encoded a-amylase. Ann Microbiol 58: 99-108.

58. Nakamura Y, Sawada T, Komatsu A (2002) Ethanol production from raw starch by a recombinant yeast having saccharification and fermentation activities. $J$ Chem Technol Biotechnol 77: 1101-1106.

59. Liao B, Hill G, Roesler W (2012) Stable expression of barley a-amylase in $S$. cerevisiae for conversion of starch into bioethanol. Biochem Eng J 64: 8-16.

60. Eksteen JM, Van Rensburg P, Cordero Otero RR, Pretorius IS (2003) Starch fermentation by recombinant Saccharomyces cerevisiae strains expressing the alpha-amylase and glucoamylase genes from Lipomyceskononenkoaeand Saccharomycopsis fibuligera. Biotechnol Bioeng 84: 639-646.

61. Soni SK, Kaur A, Gupta JK (2003) A solid state fermentation based bacteria a-amylase and fungal glucoamylase system and its suitability for the hydrolysis of wheat starch. Process Biochem 39: 185-192.

62. Wong DW, Robertson GH, Lee CC, Wagschal K (2007) Synergistic action of recombinant alpha-amylase and glucoamylase on the hydrolysis of starch granules. Protein J 26: 159-164.

63. Kim JH, Kim HR, Lim MH, Ko HM, Chin JE, et al. (2010) Construction of a direct starch-fermenting industrial strain of Saccharomyces cerevisiae producing glucoamylase, alpha-amylase and debranching enzyme. Biotechnol Lett 32 713-719.

64. Altintas MM, Ülgen KÖ, Kirdar B, Önsan ZI, Oliver SG (2003) Optimal substrate feeding policy for fed-batch cultures of $S$. cerevisiae expressing bifunctional fusion protein displaying amylolytic activities. Enzyme Microb Technol 33: 262 269.

65. Janse BJ, Pretorius IS (1995) One-step enzymatic hydrolysis of starch using a recombinant strain of Saccharomyces cerevisiae producing alpha-amylase, glucoamylase and pullulanase. ApplMicrobiol Biotechnol 42: 878-883.

66. Yamada R, Yamakawa S, Tanaka T, Ogino C, Fukuda H, et al. (2011) Direct and efficient ethanol production from high-yielding rice using a Saccharomyces cerevisiae strain that express amylases. Enzyme Microb Technol 48: 393-396.

67. Ghang DM, Yu L, Lim MH, Ko HM, Im SY, et al. (2007) Efficient one-step starch utilization by industrial strains of Saccharomyces cerevisiae expressing the glucoamylase and alpha-amylase genes from Debaryomyces occidentalis. Biotechnol Lett 29: 1203-1208.

68. Khaw TS, Katakura Y, Koh J, Kondo A, Ueda M, et al. (2006) Evaluation of performance of different surface-engineered yeast strains for direct ethanol production from raw starch. Appl Microbiol Biotechnol 70: 573-579.

69. Yamakawa S, Yamada R, Tanaka T, Ogino C, Kondo A (2010) Repeated batch fermentation from raw starch using a maltose transporter and amylase expressing diploid yeast strain. Appl Microbiol Biotechnol 87: 109-115.

70. Yamakawa S, Yamada R, Tanaka T, Ogino C, Kondo A (2012) Repeated fermentation from raw starch using Saccharomyces cerevisiae displaying both glucoamylase and a-amylase. Enzyme Microb Technol 50: 343-347.

71. Shigechi H, Uyama K, Fujita Y, Matsumoto T, Ueda M, et al. (2002) Efficien ethanol production from starch through development of novel flocculent yeast strains displaying glucoamylase and co-displaying or secreting $\alpha$-amylase. Mol Catal B Enzym 17: 179-187.

72. Guo ZP, Qiu CY, Zhang L, Ding ZY, Wang ZX, et al. (2011) Expression of aspartic protease from Neurosporacrassa in industrial ethanol-producing yeas and its application in ethanol production. Enzyme Microb Technol 48: 148-154.

73. Romanos MA, Scorer CA, Clare JJ (1992) Foreign gene expression in yeast: a review. Yeast 8: 423-488.

74. Kim HR, Im YK, Ko HM, Chin JE, Kim IC, et al. (2011) Raw starch fermentation to ethanol by an industrial distiller's yeast strain of Saccharomyces cerevisiae expressing glucoamylase and $\alpha$-amylase genes. Biotechnol Lett 33: 16431648.

75. Okano K, Zhang Q, Shinkawa S, Yoshida S, Tanaka T, et al. (2009) Efficient production of optically pure D-lactic acid from raw corn starch by using a genetically modified L-lactate dehydrogenase gene-deficient and alphaamylase-secreting Lactobacillus plantarum strain. Appl Environ Microbiol 75: 462-467.

76. Yamada R, Tanaka T, Ogino C, Fukuda H, Kondo A (2010) Novel strategy for yeast construction using d-integration and cell fusion to efficiently produce ethanol from raw starch. Appl Microbiol Biotechnol 85: 1491-1498. 
Citation: Aydemir E, Demirci S, Doğan A, Aytekin AO, Sahin F (2014) Genetic Modifications of Saccharomyces cerevisiae for Ethanol Production from Starch Fermentation: A Review. J Bioprocess Biotech 4: 180 doi: 10.4172/2155-9821.1000180

Page 8 of 8

77. Wong D, Batt S, Robertson G, Lee C, Wagschal K (2010) Chromosomal integration of both an $\alpha$-amylase and a glucoamylase gene in Saccharomyces cerevisiae for starch conversion. Ind Biotechnol 6: 112-118.

78. Chen JP, Wu KW, Fukuda $\mathrm{H}$ (2008) Bioethanol production from uncooked raw starch by immobilized surface-engineered yeast cells. Appl Biochem Biotechnol 145: 59-67.

79. Wang JJ, Wang ZY, He XP, Zhang BR (2012) Integrated expressionof the $\alpha$-amylase, dextranase and glutathione gene in an industrial brewer's yeast strain. World J Microbiol Biotechnol 28: 223-231.
80. Nieto A, Prieto JA, Sanz P (1999) Stable high-copy-number integration of Aspergillus oryzae alpha-AMYLASE cDNA in an industrial baker's yeast strain. Biotechnol Prog 15: 459-466.

81. Ma YJ, Lin LL, Chien HR, Hsu WH (2000) Efficient utilization of starch by a recombinant strain of Saccharomyces cerevisiae producing glucoamylase and isoamylase. Biotechnol Appl Biochem 31: 55-59. 